Article

\title{
Effects of Fertilization Management under WSPI on Soil Nitrogen Distribution and Nitrogen Absorption in Apple Orchard in Loess Plateau
}

\author{
Qiyun Cheng, Juanjuan Ma *, Rong Ren, Lijian Zheng, Xianghong Guo and Xihuan Sun \\ College of Water Science and Engineering, Taiyuan University of Technology, Taiyuan 030024, China; \\ chengqiyun0053@link.tyut.edu.cn (Q.C.); renrong@tyut.edu.cn (R.R.); zhenglijian@tyut.edu.cn (L.Z.); \\ guoxianghong@tyut.edu.cn (X.G.); sunxihuan@tyut.edu.cn (X.S.) \\ * Correspondence: majuanjuan@tyut.edu.cn
}

Received: 4 September 2020; Accepted: 11 September 2020; Published: 14 September 2020

\begin{abstract}
Water storage pit irrigation (WSPI) has been proven effective in improving the water use efficiency of fruit trees in Loess Plateau, but so far there are still no matching efficient fertilization management methods. A two-year experiment was conducted to explore the management strategy of fertilization under the consideration of apple production and environmental sustainability. $\mathrm{N}$ isotope tracer technique was used to study the distribution of labelled nitrogen in soil, leaf, root and fruit. Moreover, the yield in different fertilizer managements were observed to evaluate the apple production. The results showed that increasing the amount of fertilizer could increase the accumulation of fertilizer nitrogen in soil, but also increased the risk of nitrogen leaching. Under the same amount of fertilizer, split fertilization can effectively increase of fertilizer nitrogen in soil by a mean of 4.7 times. Further, N300 application with split fertilization effectively increased apple yield. The yield of N300II treatment was higher than other treatment by maximum $68.5 \%$. In addition, the root system mainly absorbed the fertilizer nitrogen applied in the current year, and the fruit mainly absorbed the fertilizer nitrogen applied in the previous year, but there was no significant difference in the leaves.
\end{abstract}

Keywords: water storage pit irrigation; fertilizer management strategy; label nitrogen; fertilization years; soil nitrogen distribution; structure nitrogen; apple yield; agricultural environment sustainability

\section{Introduction}

The climate of the Loess Plateau in North China is dry, the temperature difference in the morning and evening is large, and the intensity of sunshine is high [1,2]. These climatic characteristics have created one of China's major premium apple producing regions [3,4]. At the same time, however, these characteristics also contribute to inherent deficiencies in agricultural production, such as the lack of soil moisture and soil fertility [5,6]. In the face of these shortcomings, the traditional solution is to increase the amount of irrigation and fertilizer. However, a large number of studies have shown that, for many plants, there is a threshold for both irrigation and fertilization, and a blind increase in irrigation and fertilization does not significantly increase crop yield [7-9].

To improve the efficiency of irrigation water use and crop yield, scholars have proposed many irrigation techniques suitable for different crops and terrain [10-12]. However, the Loess Plateau in North China is windy all year round, and the salinity of irrigation water is high. Most of the orchards in this area are in the hilly area, and the slope of the ground is large. Traditional water-saving irrigation and fertilization methods cannot give full play to their effectiveness. Therefore, in view of the challenges faced by the Loess Plateau in North China, water storage pit irrigation (WSPI) uses the 
unique irrigation water infiltration method, effectively avoiding the irrigation difficulties brought about by environmental conditions [13]. A large number of studies have shown that WSPI can effectively reduce surface transpiration, increase soil moisture content in fruit tree root area, and improve water use efficiency [14-16].

However, there are few studies on the low soil fertility that is another limiting factor of agricultural production in the Loess Plateau of North China. As we know, nitrogen is an important nutrient element and an important index of soil fertility $[17,18]$. Optimizing fertilization management can improve soil fertility and promote plant growth and yield [19], and reduce the risk of environment pollution [20], such as reducing excess greenhouse gas emissions and groundwater pollution due to fertilizer leaching [21,22]. Therefore, finding effective nitrogen management that matches irrigation patterns is essential for reducing water and nitrogen losses, improving soil fertility, and improving agricultural sustainability $[23,24]$.

At present, the research on fertilization management mainly includes soil-measuring formula fertilization [25], split fertilization [26], and so on. The main focus is on independent fertilization management on plant yield and fertilizer utilization. In some studies, isotope tracing techniques were used to study nitrogen distribution in soils and plant organs $[27,28]$. However, few studies consider the distribution of fertilizer nitrogen at different time scales, especially for apple planting. Therefore, it is necessary to understand the distribution and absorption of fertilizer nitrogen at different time scales for estimating the long-term effects of fertilization on soil and plants.

It is of practical and guiding significance to explore the high efficiency fertilizer management, especially the amount and timing of fertilization, under the condition of WSPI. The main purpose of this study was to evaluate the effect of nitrogen fertilizer management mode on (1) soil fertilizer nitrogen distribution, (2) accumulation of fertilizer nitrogen in various organs of fruit trees, and (3) apple yield during fertilization year and next year.

\section{Materials and Methods}

\subsection{Site and Climatic Condition}

This field experiment was conducted in Taigu Apple Test Base $\left(112^{\circ} 29^{\prime}\right.$ E, $\left.37^{\circ} 23^{\prime} \mathrm{N}\right)$ from April to September 2018 and April to September 2019. In this location, the average annual rainfall is about $460 \mathrm{~mm}$, the average annual temperature is $9.8^{\circ} \mathrm{C}$ (Figure 1) and the soil type is mainly sandy loam (Table 1). The soil organic matter is $11.79 \mathrm{~g} \mathrm{~kg}^{-1}$, the total nitrogen is $1.01 \mathrm{~g} \mathrm{~kg}^{-1}$, the total potassium is $19.43 \mathrm{~g} \mathrm{~kg}^{-1}$, the $\mathrm{pH}$ is 8.12 , and the soil volume mass is $1.47 \mathrm{~g} \mathrm{~cm}^{-3}$.

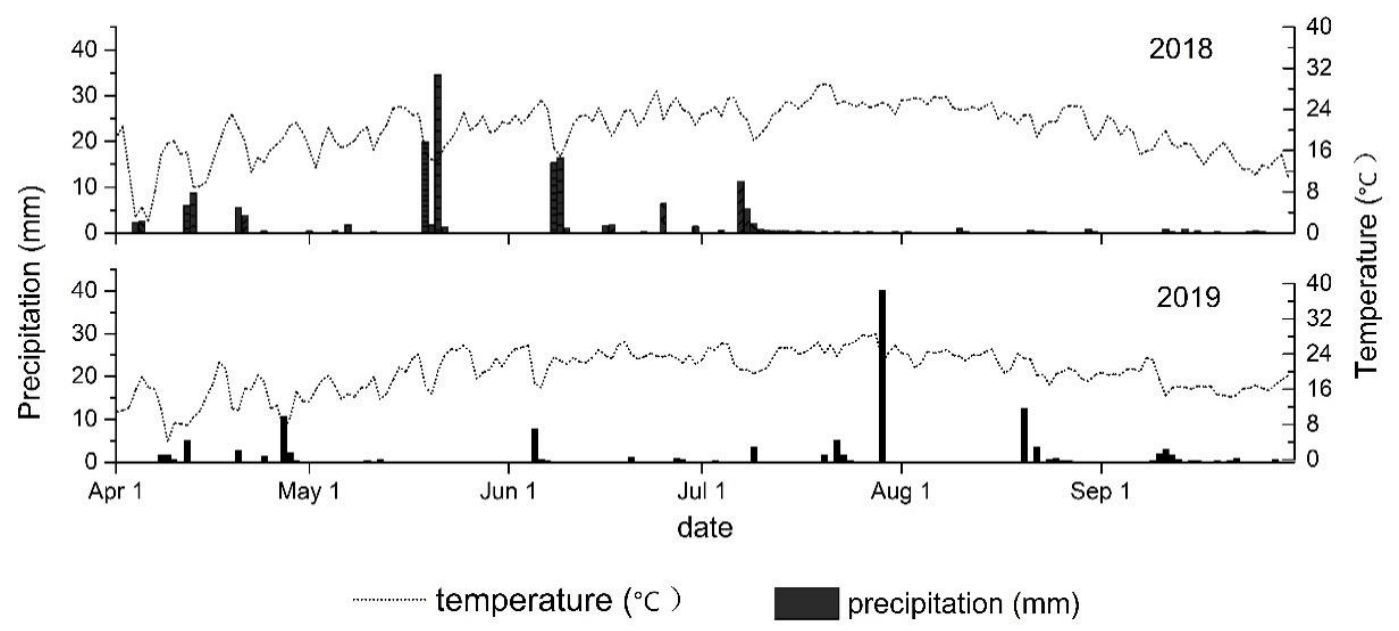

Figure 1. Precipitation and temperature during experiment in Taigu Apple Test Base. 
Table 1. Physical properties of soil in Taigu Apple Test Base.

\begin{tabular}{ccccc}
\hline Depth(cm) & Soil Texture & $\begin{array}{c}\text { Field Capacity } \\
\left(\mathbf{c m}^{\mathbf{3}} \mathbf{c m}^{-\mathbf{3}} \mathbf{)}\right.\end{array}$ & $\begin{array}{c}\text { Saturated Moisture } \\
\left(\mathbf{c m}^{\mathbf{3}} \mathbf{~ c m}^{-\mathbf{3}} \mathbf{)}\right.\end{array}$ & $\begin{array}{c}\text { Bulk Density } \\
\left(\mathbf{g ~ c m}^{-3} \mathbf{)}\right.\end{array}$ \\
\hline $0-20$ & silt loam & 0.30 & 0.51 & 1.49 \\
$20-40$ & silt loam & 0.29 & 0.52 & 1.47 \\
$40-60$ & silt loam & 0.28 & 0.52 & 1.44 \\
$60-80$ & silt loam & 0.29 & 0.48 & 1.50 \\
$80-120$ & silt loam & 0.29 & 0.44 & 1.56 \\
$120-160$ & loam & 0.32 & 0.50 & 1.45 \\
\hline
\end{tabular}

\subsection{Experimental Design}

In this study, 5 treatments were set up, including 2 irrigation methods (furrow irrigation and WSPI), 2 fertilizer amounts $\left(300 \mathrm{kgN} \mathrm{ha}^{-1}\right.$ and $\left.600 \mathrm{kgN} \mathrm{ha}^{-1}\right)$, and 2 types of fertilizer application times (single application and split applications). Each treatment was repeated 3 times. Seven-year-old apple trees were the experimental objects, which were comprised of "red fuji" section grafted onto shao series(sh), interstack, and crabapple rootstock (Malus robusta Rehd). The row spacing was $4 \mathrm{~m}$ and tree spacing was $2 \mathrm{~m}$. The irrigation method of CK treatment was furrow irrigation. The ridges were parallel to the tree rows (height of $20 \mathrm{~cm}$ ). The wide between ridges was $2 \mathrm{~m}$. The apple trees were located in bottom of furrow (Figure 2a). For WSPI, as shown in Figure 2b, the center of the storage pit was located at $1 / 2$ of the projection radius of the crown. In our study, the distance was $75 \mathrm{~cm}$ to the trunk of an apple tree. Four water storage pits were arranged around an apple tree. The depth of the water storage pit was $40 \mathrm{~cm}$, and the radius was $15 \mathrm{~cm}$. For WSPI treatment, each irrigation amount was $50 \mathrm{~mm}$ (the maximum irrigation depth of $120 \mathrm{~cm}$, and the irrigation limit of $60-90 \%$ of the field capacity), and irrigation was performed on 24 May, 19 July, and 25 August in 2018 and 9 May, 23 June, 11 July, and 18 August in 2019, respectively. For furrow treatment, the irrigation amount and date was same as the WSPI treatment.

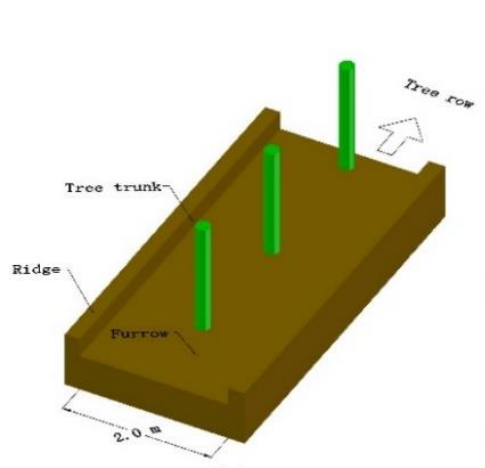

(a)

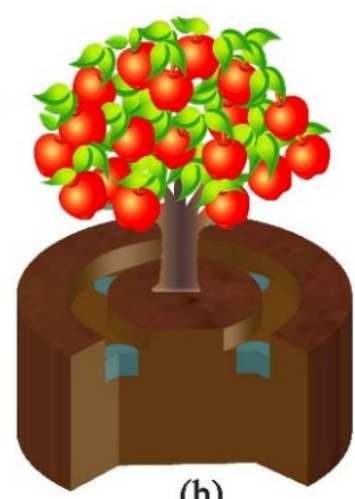

(b)

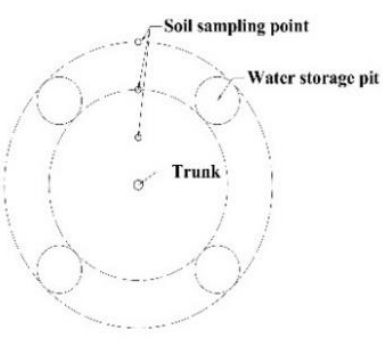

(c)

Figure 2. Schematic of the irrigation systems: (a) furrow irrigation; (b) field 3-D schematic of WSPI; (c) sampling point for WSPI.

Manure was applicated with $1000 \mathrm{~kg} \mathrm{ha}^{-1}$ as base fertilizer on 20 October in 2017 and 25 October in 2018. The manure fertilizing method was digging circular furrows at the edge of canopy projection and backfilling soil after the fertilization. The application depth is $20 \mathrm{~cm}$. The type of topdressing was urea. The fertilizer consists of ${ }^{15} \mathrm{~N}$-labeled urea (Shanghai Chemical Research Institute, $\mathrm{N}^{15}$ abundance $10.22 \%$ ) and unlabeled ordinary urea, with a ratio of 27 to 1000 . The mixed urea was applied only in 2018, and the same amount of unlabeled ordinary urea was applied in 2019.

For single fertilization treatment (N300I and N600I), the full amount of nitrogen fertilizer was applied on 24 May 2018 and 9 May 2019 (late flowering). Then, for the treatment of split fertilization (CK, N300II and N600II), the first fertilization applied half of the total amount of fertilizer at the same date as the application of single fertilization treatment, and the second fertilization applied the other 
half nitrogen fertilizer on 19 July 2018 and 11 July 2019 (fruit expansion). Moreover, only organic base fertilizer applied for N0 treatment. For furrow irrigation (CK), fertilizer was evenly scattered around a fruit tree. For water storage pit irrigation, fertilizer is evenly distributed in the storage pit. Irrigation was performed immediately after fertilization. Other field management practices were consistent with those in local orchards. The specific experimental treatment is shown in Table 2.

Table 2. The experiment treatment.

\begin{tabular}{cccc}
\hline Treatment & Irrigation Method & Fertilization Time & Fertilizer Amount (kgN ha $\left.^{-\mathbf{1}}\right)$ \\
\hline $\mathrm{CK}$ & Furrow irrigation & twice & 300 \\
$\mathrm{~N}_{300} \mathrm{I}$ & WSPI & once & 300 \\
$\mathrm{~N}_{300} \mathrm{II}$ & WSPI & twice & 300 \\
$\mathrm{~N}_{600} \mathrm{I}$ & WSPI & once & 600 \\
$\mathrm{~N}_{600} \mathrm{II}$ & WSPI & twice & 600 \\
$\mathrm{~N}_{0}$ & WSPI & none & 0 \\
\hline
\end{tabular}

\subsection{Sampling and Test Methods}

Soil samples were collected using soil drills on 20 September in 2018 and 9 May, 22 May, 26 July and 19 September in 2019. The sampling depth was $160 \mathrm{~cm}$, and one sample was taken every $20 \mathrm{~cm}$. the sampling point was shown in Figure 2c.

Fruit and root samples collected on 21 September in 2018 and 25 September in 2019. Yield measurements were carried out at the same date. Root samples were collected using root drill, sampling depth was $160 \mathrm{~cm}$. Sampling point was same as soil sampling point (Figure 2c). Leaf samples were collected on 19 September in 2018 and 20 September in 2019. Each treatment collected 12 leaves, in which 3 leaves were collected in each direction.

The soil samples and the cleaned plant samples were respectively dried, ground and sieved. Then the ${ }^{15} \mathrm{~N}$ enrichment was determined using isotope ration mass spectrometers (DeltaV, Thermo Finnigan, San Francisco, CA, USA).

\subsection{Calculation and Data Analysis}

The percentage of nitrogen absorbed from the ${ }^{15} \mathrm{~N}$-fertilizer in plant structures (leaf, root and fruit) or in soil layers was calculated as Ndff $=\left({ }^{15} \mathrm{~N}\right.$ excess of sample $/{ }^{15} \mathrm{~N}$ excess of fertilizer $) \times 100 \%$.

A single factor ANOVA application was used to analyze the data by SPSS Statistics 17.0 (IBM, Amonk, NY, USA). The Duncan test at $p<0.05$ was used to analyze significant interactions within treatments. Drawings were developed using Origin9.0 (Originlab, Northampton, MA, USA).

\section{Results}

\subsection{Fertilizer Nitrogen Residues in Soil}

There were significant differences in Ndff in shallow soils $(0-40 \mathrm{~cm})$ under different irrigation methods (CK vs. N300II). However, the differences in deep soil were not significant (Table 3 and Figure 3a). The fertilizer nitrogen of high fertilizer application treatment concentrated at $60-140 \mathrm{~cm}$ soil layer (Figure $3 \mathrm{~b}$ ) compared with that of low fertilizer application treatment. However, in single fertilization treatment (N300I and N600II), the effect of nitrogen amount on nitrogen residue was not significant (Table 3). Fertilizer nitrogen residues in 40-140 cm soil layers were significantly affected by fertilization times (Figure 3c). At low fertilizer amount treatment $\left(300 \mathrm{kgN} \cdot h \mathrm{a}^{-1}\right)$, the difference of Ndff between shallow and middle layers was significant. At high fertilizer amount treatment $\left(600 \mathrm{kgN} \cdot \mathrm{ha}^{-1}\right)$, the difference of Ndff between middle and deep layers was significant (Table 3 ). 
Table 3. The Ndff (\%) of different soil layers.

\begin{tabular}{ccccc}
\hline Treatment & Shallow $\mathbf{( 0 - 4 0 ~} \mathbf{~ c m})$ & Middle $\mathbf{( 4 0 - 1 0 0 ~} \mathbf{~ c m})$ & Deep (100-160) & Total \\
\hline CK & $13.69 \pm 5.69 \mathrm{a}$ & $7.57 \pm 9.92 \mathrm{ab}$ & $0.97 \pm 0.21 \mathrm{a}$ & $6.61 \pm 2.77 \mathrm{ab}$ \\
N300I & $1.32 \pm 0.31 \mathrm{~b}$ & $1.37 \pm 0.40 \mathrm{a}$ & $0.83 \pm 0.12 \mathrm{a}$ & $1.14 \pm 0.13 \mathrm{a}$ \\
N300II & $3.22 \pm 2.40 \mathrm{ab}$ & $7.47 \pm 2.38 \mathrm{ab}$ & $0.93 \pm 0.15 \mathrm{a}$ & $3.96 \pm 1.22 \mathrm{a}$ \\
N600I & $2.18 \pm 1.30 \mathrm{~b}$ & $1.30 \pm 0.46 \mathrm{a}$ & $0.80 \pm 0.17 \mathrm{a}$ & $1.33 \pm 0.28 \mathrm{a}$ \\
N600II & $1.79 \pm 0.17 \mathrm{~b}$ & $16.37 \pm 8.29 \mathrm{~b}$ & $10.73 \pm 7.74 \mathrm{~b}$ & $10.61 \pm 3.02 \mathrm{~b}$ \\
\hline
\end{tabular}

Statistically significant differences $(p<0.05)$ in the same column are indicated by different letters.

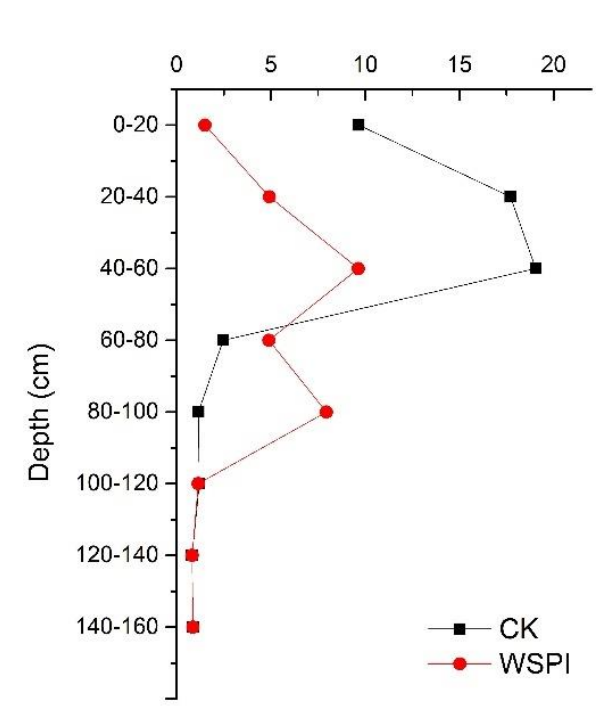

(a)

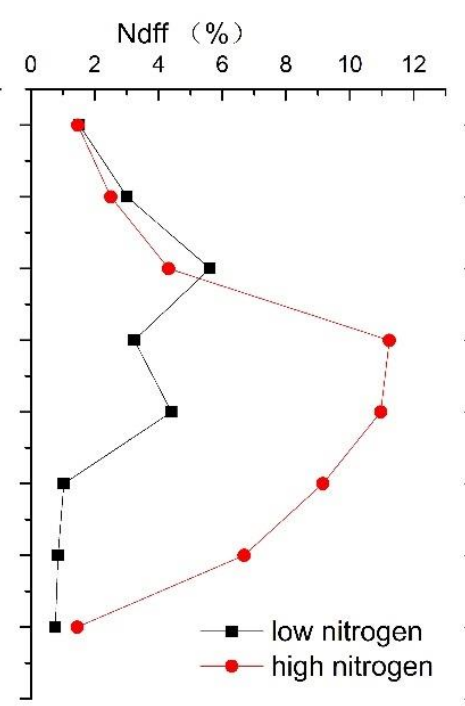

(b)

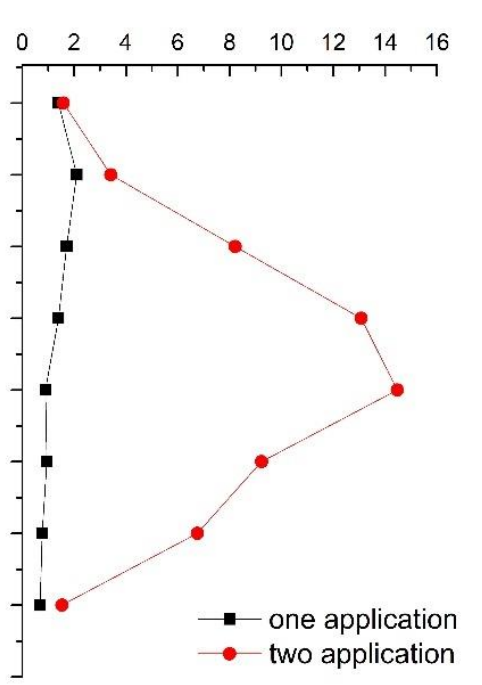

(c)

Figure 3. The distribution of Ndff (\%) in different depth: (a) CK and WSPI, the data of WSPI from N300II. (b) N300 and N600, the data from WSPI treatment. (c) single application and split application, the data from WSPI treatment.

\subsection{Change of Fertilizer Nitrogen Residues in Next Year}

There were differences in nitrogen residues of labeled fertilizer in the second year (Figure 4). On the whole, the distribution of fertilizer nitrogen in each soil layer was similar to that in the current year, and that under WSPI was mainly concentrated in the middle and deep layers, and that under furrow irrigation was mainly concentrated in the shallow and middle layers. The labeled nitrogen residues of high nitrogen amount were more than that of low nitrogen amount in each layer. In addition, split fertilization increased the accumulation of labeled nitrogen in soil layers compared to single fertilization. Notably, the detection on 22 May 2019 showed a significant increase in the deep soil of the N600II treatment. And, the labeled nitrogen in the shallow and middle layers decreased. This may be due to the fact that irrigation promoted the migration of labeled nitrogen to the deep soil. Moreover, the detection on 19 September 2019 showed that, only in N600II treatment, labeled nitrogen in deep soil was higher than that in middle soil.

\subsection{The Distribution of Labelled N in Tree Organs}

There were significant differences in the nitrogen ratio of apple tree fruits, leaves and roots under different treatments (Table 4). For fruit, the fertilizer nitrogen ratio of twice application treatment (N300II and N600II) was significantly higher than that of other treatments in both years. For leaves, two applications with high nitrogen amount (N600II) significantly increased the fertilizer nitrogen content of leaf. The concentration of leaf fertilizer nitrogen treated with high amount once application (N600I) and furrow irrigation (CK) was significantly lower than that of other treatments in both years. 
For roots, the fertilizer nitrogen ration with low nitrogen amount was higher than that with high nitrogen amount in 2018 (N300I > N600I and N300II > N600II). However, the root content of labeled fertilizer nitrogen in 2019 was different from that in 2018. Further, the root uptake of low nitrogen amount treatment was significantly lower than that of high nitrogen amount treatment $(\mathrm{N} 300 \mathrm{I}<\mathrm{N} 600 \mathrm{I}$ and N300II < N600II).

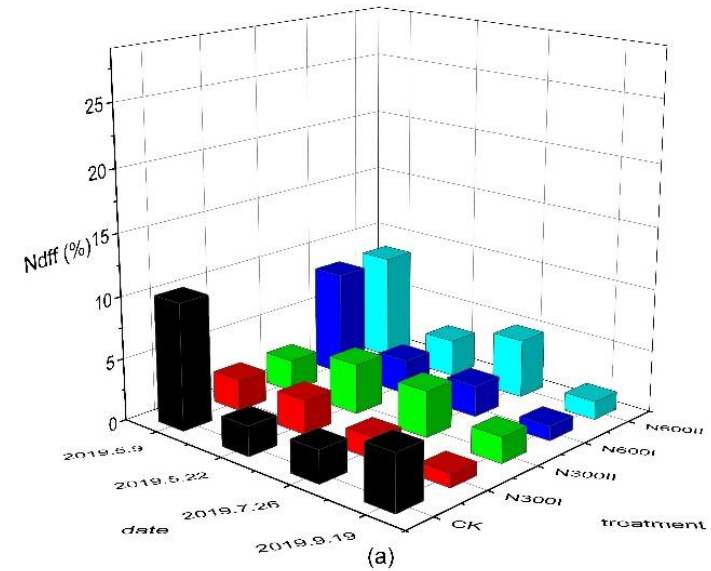

(a)

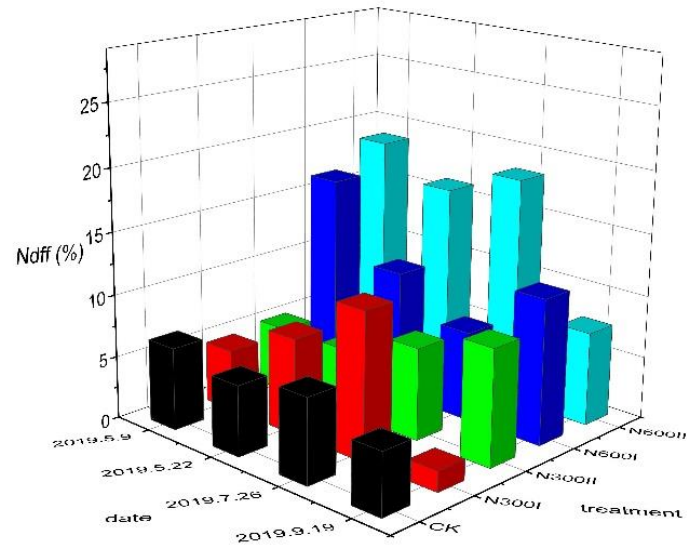

(b)

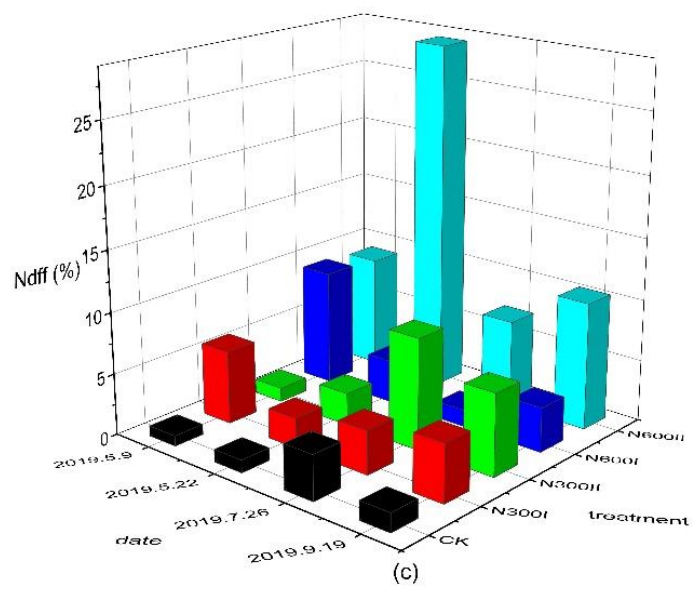

Figure 4. Residues of fertilizer nitrogen applicated in previous year: (a) fertilizer nitrogen residues in shallow layer; (b) fertilizer nitrogen residues in middle layer; (c) fertilizer nitrogen residues in deep layer.

Table 4. Ndff (\%) in apple tree structures.

\begin{tabular}{ccccccc}
\hline \multirow{2}{*}{ Treatment } & \multicolumn{5}{c}{$\mathbf{2 0 1 8}$} & \multicolumn{2}{c}{$\mathbf{2 0 1 9}$} \\
\cline { 2 - 7 } & Fruit & Leaf & Root & Fruit & Leaf & Root \\
\hline CK & $3.36 \pm 0.73 \mathrm{a}$ & $2.87 \pm 0.59 \mathrm{a}$ & $5.40 \pm 0.53 \mathrm{a}$ & $9.62 \pm 0.45 \mathrm{a}$ & $3.11 \pm 0.61 \mathrm{a}$ & $7.46 \pm 0.36 \mathrm{a}$ \\
$\mathrm{N}_{300} \mathrm{I}$ & $6.06 \pm 0.65 \mathrm{~b}$ & $9.83 \pm 0.63 \mathrm{bc}$ & $27.20 \pm 0.52 \mathrm{~b}$ & $11.55 \pm 0.66 \mathrm{a}$ & $9.96 \pm 0.99 \mathrm{~b}$ & $17.21 \pm 0.15 \mathrm{~b}$ \\
$\mathrm{~N}_{300 \mathrm{II}}$ & $11.83 \pm 0.71 \mathrm{c}$ & $8.33 \pm 0.98 \mathrm{~b}$ & $22.56 \pm 0.33 \mathrm{c}$ & $32.13 \pm 0.75 \mathrm{~b}$ & $6.77 \pm 0.85 \mathrm{c}$ & $13.80 \pm 0.23 \mathrm{c}$ \\
$\mathrm{N}_{600} \mathrm{I}$ & $5.98 \pm 0.45 \mathrm{~b}$ & $3.74 \pm 0.86 \mathrm{a}$ & $24.39 \pm 0.22 \mathrm{~d}$ & $10.57 \pm 0.83 \mathrm{a}$ & $2.50 \pm 0.44 \mathrm{a}$ & $23.29 \pm 0.51 \mathrm{~d}$ \\
$\mathrm{~N}_{600} \mathrm{II}$ & $11.58 \pm 0.79 \mathrm{c}$ & $17.71 \pm 1.14 \mathrm{~d}$ & $17.07 \pm 0.45 \mathrm{e}$ & $21.33 \pm 0.64 \mathrm{c}$ & $11.85 \pm 0.92 \mathrm{c}$ & $22.12 \pm 0.21 \mathrm{e}$ \\
\hline
\end{tabular}

\subsection{The Yield of Apple}

Irrigation and fertilization management have a significant impact on apple yield (Figure 5). Compared with single fertilization treatments, split fertilization treatments with the same amount of fertilizer significantly increased apple yield under WSPI. High fertilizer amount application decreased the apple yield, but the difference was not significant. Moreover, under the same fertilizer management, 
WSPI increased the apple yield significant, compared with the traditional furrow irrigation. The yield of N300II treatment was higher by maximum $68.5 \%$.

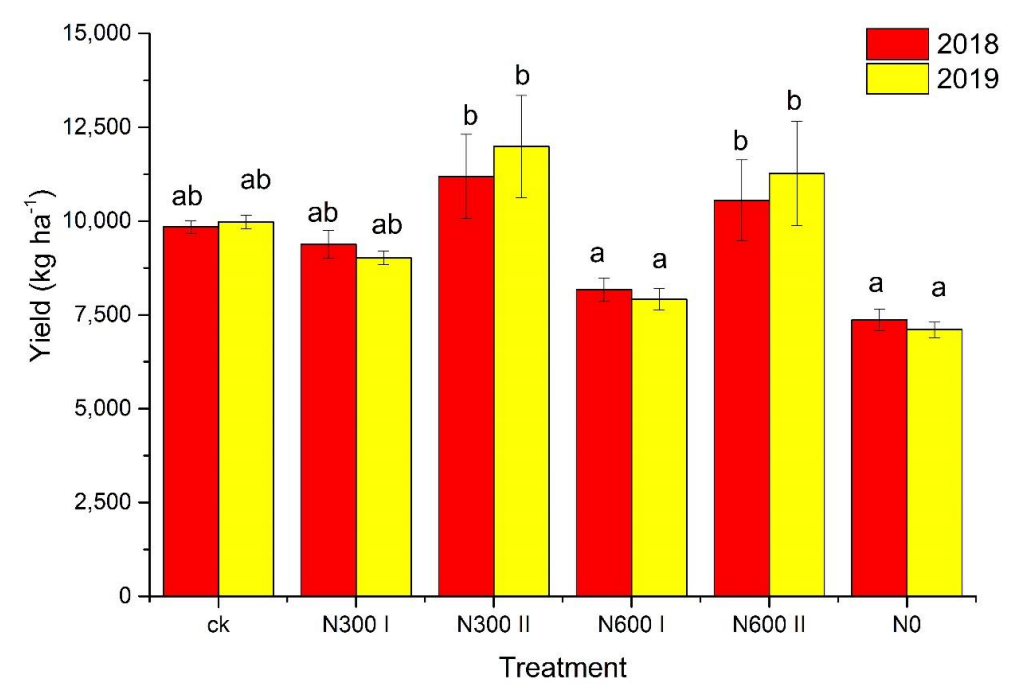

Figure 5. Apple yields of different treatment. Statistically significant differences $(p<0.05)$ are indicated by different letters.

\section{Discussion}

Rational irrigation and fertilization can effectively promote plant growth and yield, but excessive irrigation and fertilization reduce the water and fertilizer use efficiency [29,30], even causing environment pollution [21,22]. The difference of irrigation methods impacts the distribution of soil moisture [31,32]. Our research indicated that the irrigation method also affects the distribution of fertilizer nitrogen. Compared with furrow irrigation, WSPI can effectively reduce the accumulation of nitrogen in shallow layer (Table 3 and Figure 3a), which could reduce the potential risk of ammonia volatilization [33]. Moreover, the change of fertilization management also affects the distribution of fertilizer nitrogen. The content of fertilizer nitrogen in middle layer in N300II treatment was significantly higher than that in other treatments under WSPI (Table 3 and Figure 3). The result of Wu showed that split application could improve soil nitrogen levels [34]. The fertilization management which was split application with low nitrogen amount not only reduced shallow nitrogen residue but also did not increase deep nitrogen leaching significantly. This may be due to the direct infiltration of the fertilizer solution into the middle soil $(40-100 \mathrm{~cm})$ through the water storage pit [16], which reduces the adsorption of nitrogen from the shallow soil to the fertilizer nitrogen. And the amount of each fertilization was not enough to induce nitrogen leaching. In agricultural production, soil nitrogen is an important part of soil fertility. It is important to improve soil fertility for sustainable orchard production. In this study, the fertilization management of two fertilizations with high nitrogen (N600II) amount promotes the fertilizer nitrogen concentrate in deep layer in the second year. However, the low nitrogen application mode concentrated the fertilizer nitrogen in middle layer in the second year (Figure 4). It can be speculated that high nitrogen application could increase the risk of nitrogen leaching and increase the risk of groundwater pollution in long-term fertilization. A similar conclusion was showed by Bohman [35].

In this study, we found that there were differences in utilization strategies of fertilizer nitrogen that applicated in different years among apple tree structures (Table 4). In low nitrogen application treatment (N300), the roots were more likely to use fertilizer nitrogen applicated in the current year, and the fruit was more likely to use that application in the previous year. However, there was not significant difference in leaves uptake fertilizer nitrogen application in different years. This may be related to the nitrogen use strategy of apple tree as perennial trees. Perennial trees redistribute the absorbed nitrogen at the end of growth, and storage some of it in some structures preparing for next 
year [36]. Further, some scholars suggested that nitrogen application will affect the performance of rhizosphere microorganisms, and then affect the absorption of nutrients by plants [37]. In addition, a large number of studies have shown a significant correlation between fertilization management and agricultural yields [38-40]. In this study, the yield of twice fertilization with low nitrogen amount (N300II) was highest among the treatments in both years. This fertilization management method could significantly increase apple yield in Loess Plateau.

In summary, at the same fertilization conditions, WSPI can promote the concentration of fertilizer in the middle soil, reduce the accumulation of nitrogen in the surface soil, and reduce the risk of ammonia volatilization. However, high nitrogen application (N600) increases the transport of fertilizer nitrogen to the deep soil, which may increase the risk of deep leaching. Compared with single fertilization, split fertilization can promote the nitrogen residue in the soil for a long time, and at the same time, split fertilization can significantly increase apple yield.

\section{Conclusions}

Water storage pit irrigation can effectively reduce the accumulation of nitrogen in the shallow layer and reduce the risk of gas loss of fertilizer nitrogen. Under the WSPI method, fertilizer nitrogen in the soil increases with the amount of fertilizer applied. However, a high amount of fertilizer application increased the risk of nitrogen leaching and the accumulation of soil nitrogen in the next year. Under the condition of the same amount of fertilizer, split fertilization can effectively increase the nitrogen residue in the middle soil fertilizer. Further, there were differences in the utilization strategies of fertilizer nitrogen applicated in different years among apple tree structures. The roots were more likely to use fertilizer nitrogen applicated in the current year, and the fruit was more likely to use that application in the previous year. However, there was no significant difference in leaves uptake of fertilizer nitrogen application in different years. Moreover, split fertilization with low nitrogen application effectively increased apple yield. Therefore, considering the impact on the environment, the impact on long-term soil fertility, and the yield of apples, the irrigation and fertilization management method that is split fertilization with low nitrogen amount $\left(300 \mathrm{kgn} \cdot \mathrm{ha}^{-1}\right)$ based on WSPI is suitable for the apple orchard in the Loess Plateau of North China.

Author Contributions: Conceptualization, X.S. and J.M.; investigation, Q.C. and R.R.; resources, X.G.; data curation, Q.C.; writing-original draft preparation, Q.C.; writing-review and editing, Q.C. and R.R.; supervision, R.R.; project administration, J.M. and L.Z.; funding acquisition, J.M. and X.G. All authors have read and agreed to the published version of the manuscript.

Funding: This research was funded by National Natural Science Foundation of China, grant number 51579168 and Natural Science Foundation of Shanxi Province, grant number 2016D011053.

Acknowledgments: We acknowledge the support from Fruit Tree Institue, Shanxi Academy of Agricultural Sciences for orchards available.

Conflicts of Interest: The authors declare no conflict of interest.

\section{References}

1. Wang, Y.J.; Liu, L.; Wang, Y.; Tao, H.X.; Fan, J.L.; Zhao, Z.Y.; Guo, Y.P. Effects of soil water stress on fruit yield, quality and their relationship with sugar metabolism in Gala apple. Sci. Hortic. 2019, 258, 108753. [CrossRef]

2. Wang, D.; Wang, L. Dynamics of evapotranspiration partitioning for apple trees of different ages in a semiarid region of northwest China. Agric. Water Manag. 2017, 191, 1-15. [CrossRef]

3. Xu, M.D.; Xiao, W.L.; Liu, H.; Song, S.Q. Preparation of pure natural apple powder. Food Sci. Technol. 2014, 39, 92-95, (In Chinese with English abstract).

4. Song, X.L.; Gao, X.D.; Zhao, X.N.; Wu, P.; Dyck, M. Spatial distribution of soil moisture and fine roots in rain-fed apple orchards employing a Rainwater Collection and Infiltration (RWCI) system on the Loess Plateau of China. Agric. Water Manag. 2017, 184, 170-177. [CrossRef] 
5. Liu, Z.J.; Ma, P.Y.; Zhai, B.N.; Zhou, J.B. Soil moisture decline and residual nitrate accumulation after converting cropland to apple orchard in a semiarid region: Evidence from the Loess Plateau. Catena 2019, 181, 104080. [CrossRef]

6. Du, S.; Kang, S.; Li, F.; Du, T. Water use efficiency is improved by alternate partial root-zone irrigation of apple in arid northwest china. Agric. Water Manag. 2017, 179, 184-192. [CrossRef]

7. Shu, L.Z.; Liu, R.; Min, W.; Wang, Y.S.; Yu, H.; Zhu, P.F.; Zhu, J.R. Regulation of soil water threshold on tomato plant growth and fruit quality under alternate partial root-zone drip irrigation. Agric. Water Manag. 2020, 238, 106200. [CrossRef]

8. Jia, Q.M.; Yang, L.Y.; An, H.Y.; Dong, S.; Chang, S.H.; Zhang, C.; Liu, Y.J.; Hou, F.J. Nitrogen fertilization and planting models regulate maize productivity, nitrate and root distributions in semi-arid regions. Soil Tillage Res. 2020, 200, 104636. [CrossRef]

9. Lyu, Y.; Porat, R.; Yermiyahu, U.; Heler, Y.; Holland, D.; Dag, A. Effects of nitrogen fertilization on pomegranate fruit, aril and juice quality. J. Sci. Food Agric. 2019, 100, 1678-1686. [CrossRef]

10. Luo, H.H.; Zhang, Y.L.; Zhang, W.F. Effects of water stress and rewatering on photosynthesis, root activity, and yield of cotton with drip irrigation under mulch. Photosynthetica 2016, 54, 65-73. [CrossRef]

11. Ippolito, J.A.; Bkorneberg, D.L.; Blecker, S.W.; Massey, M.S. Mechanisms responsible for soil phosphorus availability differences between sprinkler and furrow irrigation. J. Environ. Qual. 2019, 48, 1370-1379. [CrossRef] [PubMed]

12. Topak, R.; Acar, B.; Uyanoz, R.; Ceyhan, E. Performance of partial root-zone drip irrigation for sugar beet production in a semi-arid area. Agric. Water Manag. 2016, 176, 180-190. [CrossRef]

13. Sun, X.H.; Ma, J.J.; Guo, X.H. Water storage pit irrigation technique. In Proceedings of the International Conference on Effective Utilization of Agricultural Soil and Water Resources and Protection of Environment on the 4th Annual Academic Conference of Chinese Society of Agricultural Soil and Water Engineering, Nanjing, China, 16 August 2006; Hohai University Press: Nanjing, China, 2006; pp. 211-214.

14. Zheng, L.J.; Ma, J.J.; Sun, X.H.; Guo, X.H.; Li, Y.Y.; Ren, R.; Cheng, Q.Y. Effective root growth zone of apple tree under water storage pit irrigation using stable isotope methodology. Arch. Agron. Soil Sci. 2019, 65, 1521-1535. [CrossRef]

15. Ren, R.; Ma, J.J.; Cheng, Q.Y.; Zheng, L.J.; Guo, X.H.; Sun, X.H. An Investigation into the Effects of Temperature Gradient on the Soil Water-Salt Transfer with Evaporation. Water 2017, 9, 456. [CrossRef]

16. Guo, X.H.; Lei, L.; Sun, X.H.; Ma, J.J.; Zheng, L.J.; Zhang, S.W.; He, Q.Q. Modeling soil water dynamics and root water uptake for apple trees under water storage pit irrigation. Int. J. Agric. Biol. Eng. 2019, 12, $126-134$. [CrossRef]

17. Bangroo, S.A.; Najar, G.R.; Achin, E.; Truong, P.N. Application of predictor variables in spatial quantification of soil organic carbon and total nitrogen using regression kriging in the North Kashmir forest Himalayas. Catena 2020, 193, 104632. [CrossRef]

18. Wang, X.; Guo, X.; Yu, Y.; Cui, H.; Wang, R.Q.; Guo, W.H. Increased nitrogen supply promoted the growth of non-Nfixing woody legume species but not the growth of N-fixing Robinia pseudoacacia. Sci. Rep. 2018, 8 , 17896. [CrossRef]

19. Sete, P.B.; Comin, J.J.; Ciotta, M.N.; Salume, J.A.; Thewes, F.; Brackmann, A.; Toselli, M.; Nava, G.; Rozane, D.E.; Loss, A.; et al. Nitrogen fertilization affects yield and fruit quality in pear. Sci. Hortic. 2019, 258, 108782. [CrossRef]

20. Xia, L.L.; Lam, S.K.; Wang, S.W.; Zhou, W.; Chen, D.L.; Yan, X.Y. Optimizing nitrogen fertilization rate to enhance soil carbon storage and decrease nitrogen pollution in paddy ecosystems with simultaneous straw incorporation. Agric. Ecosyst. Environ. 2020, 298, UNSP106968. [CrossRef]

21. Abalos, D.; Sanchez-Martin, L.; Garcia-Torres, L.; van Groenigen, J.W.; Vallejo, A. Management of irrigation frequency and nitrogen fertilization to mitigate GHG and NO emissions from drip-fertigated crops. Sci. Total Environ. 2014, 490, 880-888. [CrossRef]

22. Xu, J.T.; Cai, H.J.; Wang, X.Y.; Ma, C.G.; Lu, Y.J.; Lu, Y.B.; Ding, Y.B.; Wang, X.W.; Chen, H.; Wang, Y.F.; et al. Exploring optimal irrigation and nitrogen fertilization in a winter wheat-summer maize rotation system for improving crop yield and reducing water and nitrogen leaching. Agric. Water Manag. 2020, 228, 105904. [CrossRef]

23. Ierna, A.; Mauromicale, G. Sustainable and profitable nitrogen fertilization management of potato. Agron. Basel 2019, 9, 582. [CrossRef] 
24. Xu, J.T.; Wang, X.Y.; Ding, Y.B.; Mu, Q.; Cai, H.J.; Ma, C.G.; Saddique, Q. Effects of irrigation and nitrogen fertilization management on crop yields and long-term dynamic characteristics of water and nitrogen transport at deep soil depths. Soil Tillage Res. 2020, 198, 104536. [CrossRef]

25. Qi, Y.; Leng, Y.Y.; Wang, M.; Hu, Y.A.; Bai, Y.E. Design of Decision Support System for Soil Testing and Formula Fertilization based on the Intelligent Agriculture. In Proceedings of the 4th International Conference on Machinery, Materials and Information Technology Applications, Xian, China, 10-11 December 2016; Atlantis Press: Paris, France, 2016; Volume 71, pp. 1402-1407.

26. Du, X.B.; Zhang, X.Y.; Xi, M.; Kong, L.C. Split application enhances sweetpotato starch production by regulating the conversion of sucrose to starch under reduced nitrogen supply. Plant Physiol. Bioch. 2020, 151, 743-750. [CrossRef]

27. Jiao, F.; Wu, J.H.; Yu, L.H.; Zhai, R.C. N-15 tracer technique analysis of the absorption and utilisation of nitrogen fertiliser by potatoes. Nutr. Cycl. Agroecosyst. 2013, 95, 345-351. [CrossRef]

28. Xia, M.J.; Chen, Z.J.; Gao, J.B.; Liu, Z.J.; Li, H.X.; Zhou, J.B. Summer fallow increases loss of residual nitrogen fertilizer in dryland of the Loess Plateau: A 15N-labeled method. Environ. Sci. Pollut. Res. 2018, 25, 34155-34163. [CrossRef] [PubMed]

29. Campelo, D.H.; Teixeira, A.D.; Moreira, L.C.J.; de Lacerda, C.F. Growth, production and water and nitrogen use efficiency of maize under water depths and nitrogen fertilization. Revista Brasileira Engenharia Agrícola Ambiental 2019, 23, 747-753. [CrossRef]

30. Hu, X.H.; Qu, F.; Jiang, J.J.; Xu, J.W.; Liu, T. Drip irrigation and fertilization improve yield, uptake of nitrogen, and water-nitrogen use efficiency in cucumbers grown in substrate bags. Plant Soil Environ. 2019, 65, 328-335. [CrossRef]

31. Bajpai, A.; Kaushal, A. Soil moisture distribution under trickle irrigation: A review. Water Supply 2020, 20, 761-772. [CrossRef]

32. Chen, W.L.; Jin, M.G.; Ferre, T.P.A.; Liu, Y.F.; Xian, Y.; Shan, T.R.; Ping, X. Spatial distribution of soil moisture, soil salinity, and root density beneath a cotton field under mulched drip irrigation with brackish and fresh water. Field Crop. Res. 2018, 215, 207-221. [CrossRef]

33. Tang, Y.H.; Cui, Z.Y.; Peng, D.L.; Yin, Y.P.; Li, Y.; Wang, Z.L. Ammonia emission from soil water of wheat field as affected by different nitrogen and irrigation strategies. In Proceedings of the 4th Annual Science and Technology Conference (Tesseract), Gandhinagar, India, 10-12 November 2017; Desalination and Water Treatment: Hopkinton, MA, USA, 2018; Volume 125, pp. 258-264. [CrossRef]

34. Wu, Y.; Sun, M.D.; Liu, J.; Wang, W.J.; Liu, S.Z. Fertilizer and soil nitrogen utilization of pear tree as affected by the timing of split fertilizer application in rain-fed orchard. Sci. Hortic. 2019, 252, 363-369. [CrossRef]

35. Bohman, B.J.; Rosen, C.J.; Mulla, D.J. Impact of variable rate nitrogen and reduced irrigation management on nitrate leaching for potato. J. Environ. Qual. 2020, 49, 281-291. [CrossRef]

36. Morris, M.; Swarts, N.D.; Dietz, C.; Close, D.C. Uptake efficiency and internal allocation of nitrogen in apple trees. In Proceedings of the 8th International Symposium on Mineral Nutrition of Fruit Crops, Bolzano, Italy, 27 June 2017; Acta Horticulturae: Leuven, Belgium, 2018; Volume 1217, pp. 53-59. [CrossRef]

37. Kastl, E.M.; Schloter-Hai, B.; Buegger, F.; Schloter, M. Impact of fertilization on the abundance of nitrifiers and denitrifiers at the root-soil interface of plants with different uptake strategies for nitrogen. Biol. Fert. Soils 2015, 51, 57-64. [CrossRef]

38. Shajari, M.A.; Moghaddam, P.R.; Ghorbani, R.; Koocheki, A. The possibility of improving saffron (Crocus sativus L.) flower and corm yield through the irrigation and soil texture managements. Sci. Hortic. 2020, 271, 109485. [CrossRef]

39. Jing, B.; Shah, F.R.; Xiao, E.S.; Coulter, J.A.; Wu, W. Sprinkler irrigation increases grain yield of sunflower without enhancing the risk of root lodging in a dry semi-humid region. Agric. Water Manag. 2020, 239, UNSP106270. [CrossRef]

40. Hou, P.F.; Yu, Y.L.; Xue, L.X.; Petropoulos, E.; He, S.Y.; Zhang, Y.S.; Pandey, A.; Xue, L.H.; Yang, L.Z.; Chen, D.L. Effect of long-term fertilization management strategies on methane emissions and rice yield. Sci. Total Environ. 2020, 725, 138261. [CrossRef]

(C) 2020 by the authors. Licensee MDPI, Basel, Switzerland. This article is an open access article distributed under the terms and conditions of the Creative Commons Attribution (CC BY) license (http://creativecommons.org/licenses/by/4.0/). 